\title{
ANALYSIS OF EMPLOYEES COMPETENCIES IN THE INDUSTRY 4.0
}

\author{
G. A. Pollack ${ }^{1}$, pollakga@susu.ru, \\ O.V.Ufimtseva ${ }^{1}$, ufimtcevaov@susu.ru \\ ${ }^{1}$ South Ural State University, Chelyabinsk, Russian Federation
}

\begin{abstract}
The development of enterprises in the framework of Industry 4.0 requires professional and personal development of each employee. One of the most famous concepts of enterprise management is the Total Performance Scorecard (TPS). This system integrates the Organizational Balanced Scorecard (OBSC) and Personal Balanced Scorecard (PBSC). Ideas embedded in concepts OBSC and PBSC are combined by common indicators, which are associated with the results of development and training of each employee.

At Russian enterprises, many ERP systems are created on the software "1C: Enterprise Platform". The article proposes a module that extends the capabilities of the ERP-system, which allows creating feedback between OBSC and PBSC.

Keywords: strategic management; strategic goals; Personal Balanced Scorecard (PBSC); key performance indicators (KPI); software "1C: Enterprise Platform".
\end{abstract}

\section{Acronyms and Abbreviations}

TPS - Total Performance Scorecard

OBSC - Organizational Balanced Scorecard

PBSC - Personal Balanced Scorecard

ERP - Enterprise Resource Planning

KPI - Key Performance Indicators

TM - Talent Management

TQM - Total Quality Management

\section{Introduction}

The industrial revolution, which is commonly referred to as Industry 4.0, entails tremendous changes that encompass different aspects of life, and primarily the labor market. Steady growth and development of any company in new conditions largely depends on the effectiveness of its employees, their motivation, which increases the role of highly skilled professionals.

Strategic management of any company focuses production activities on the needs of consumers, responds flexibly and makes timely changes that meet external challenges. The goal of proper management is to gain competitive preference that can give the company an opportunity to survive in long-term outlook $[1,2,3,4]$.

During the development of administrative resolutions it is advisable to use the system of key indicators which are:

- very important for the rating of company operation;

- estimated in a quantitative sense;

- measured and tracked easily. 
One of the most famous concepts of organization management is the Total Performance Scorecard (TPS), which combines the ideas of the Organizational Balanced Scorecard (OBSC), Personal Balanced Scorecard (PBSC) [5, 6, 7], Talent Management (TM) and Total Quality Management (TQM). All these provisions are based on a process of continuous and gradual improvement, development and training employers. It is expected that as a result, the efficiency of each employee and the organization as a whole will increase (Fig.1) [8].

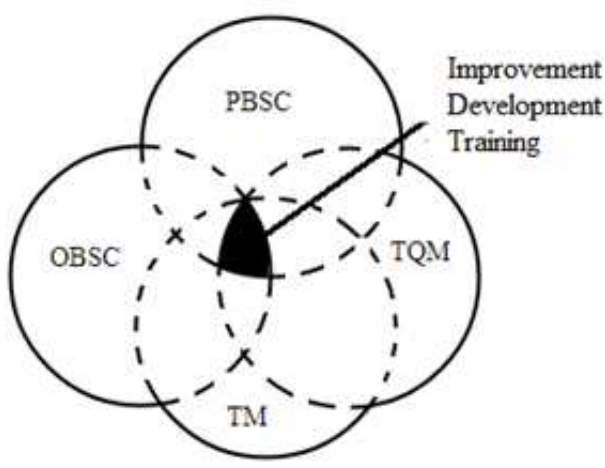

Fig. 1. Interrelation of the concepts [8]

OBSC takes into account not only financial, but also non-financial indicators of the enterprise, reflecting four important aspects of activity:

- internal business processes;

- customer relationship;

- the state of personnel and the development of internal infrastructure;

- financial.

Total Quality Management (TQM) requires great changes in the thinking of each employee of the company and in the methods of production. Everyone in the organization tries to improve the work performed. The improvement may, for example, include cost reduction, reduced time on the job, the desire to avoid losses, the active participation of all employees in the work on the goals of the organization.

Talent management (TM) system allows to evaluate the effectiveness of personnel management to support and implement the strategic goals of the company. This assessment enables the recruitment, use and retention of staff that make a significant contribution to the development of the organization.

The application of the organizational balanced scorecard (OBSC) provides an opportunity to analyze strategic and tactical management processes, to establish causeeffect relationships between various aspects of the enterprise and the degree of their mutual influence.

Personal balanced scorecard (PBSC) allows to transfer the strategy of the enterprise to the personal development plan of each employee.

Elements of PBSC can also be divided into four groups corresponding to the four aspects of the employee's activities. These aspects, which are of great importance for personal growth, are as follows: 
- internal ones, i.e. physical health and mental state;

- external ones, i.e. relationships with other people;

- knowledge and ability to learn;

- financial stability.

Therefore, a personal balanced scorecard (PBSC) allows to connect the company's strategy with personal development plans and training of each employee. This creates a "feedback" between the company's management and the employee. This allows to assess the contribution of each employee to the achievement of the company's strategic goal.

One of the main ideas in the basis of balanced scorecard is the idea of measurability. All the factors that are important for the management of the enterprise should be measured and presented in the form of interconnected and balanced key performance indicators (KPI) $[5,6,2,9,10,11]$.

Performance indicators can be fixed both for the enterprise itself and for each subdivision and employee.

\section{Realization of the Analysis of Competencies of Employees in the Industry 4.0}

Most industrial enterprises use corporate information systems built on the "1C: Enterprise Platform 8.3".

In this paper, we demonstrate an example, which shows how it is possible on the basis of this platform to realize real-time analysis of the performance indicators of each employee and to assess the degree of their impact on the performance of the enterprise as a whole.

For example, to estimate the performance indicators of each employee we can make up a list of personal tasks:

- earn the respect of customers;

- improve leadership skills;

- find inner calmness;

- improve their knowledge.

The following key performance indicators are necessary to estimate the attainability of every personal targets.

Target 1. Earn the respect of customers.

Indicators. Effective problem solving, proactivity, ability to influence, effective decision-making.

Target 2. Improve leadership skills.

Indicators. Ability to prioritize, skill to work in team, organizational awareness.

Target 3. Get inner satisfaction.

Indicator. Self-awareness.

Target 4. Improve their knowledge.

Indicators. Ability to learn, technical savvy.

On the basis of "1C: Enterprise Platform 8.3", we show how to implement the information system for the analysis in real-time performance indicators of each employee. 
For valuable analysis of balanced indicator system it is necessary to have the possibility of storing in database the information about the goals of enterprise strategic development, the key indicators of succeeding, the measures to be taken, etc. Moreover, in order to plan the strategy and analysis of enterprise development it is necessary to store the history of indicators, to compare assembled information using reports and diagrams.

It is required to introduce into the pattern some additional catalogues and registers as well as necessary reporting.

The following information is referred to supplemental one:

- personal targets ("Personal targets" catalog);

- targets of succeeding ("Indicators" catalog);

- measures that are taken to attain strategic targets ("Strategic measures" catalog).

For example, the catalog "Personal targets" has the following structure (Fig. 2).

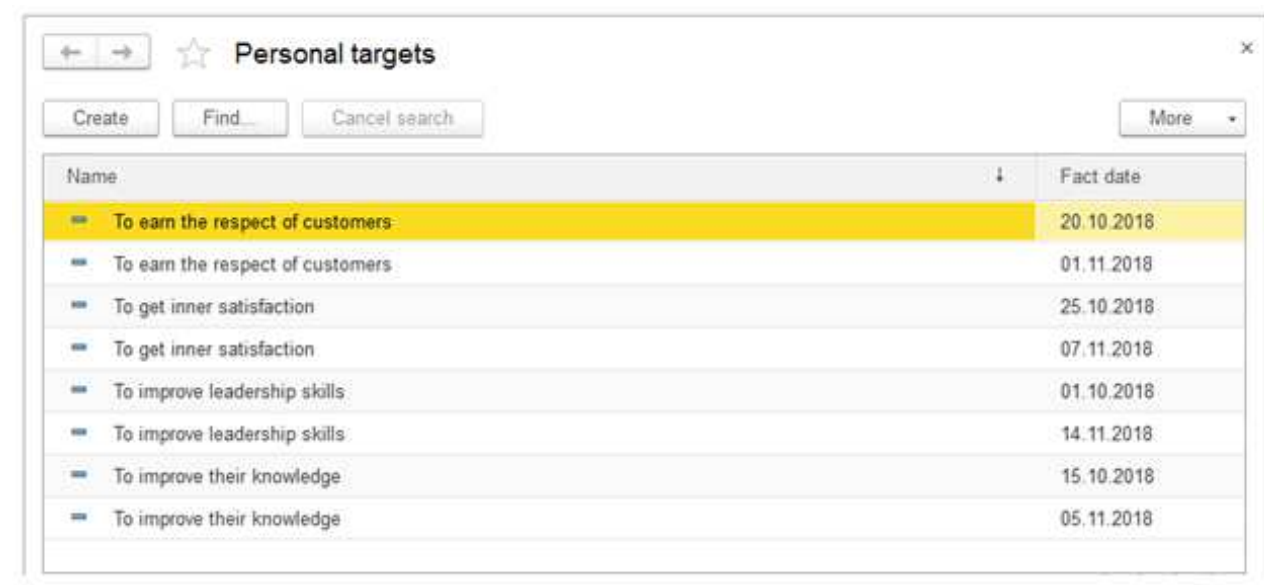

Fig. 2. Structure of the catalog "Personal targets"

Fig. 2 shows the Personal Targets guide, which contains an assessment of the tasks performance at different time periods.

Every personal target has a list of indicators that influences its implementation (Figs. 3 - 4). As some indicators influence on the attainment rate unequally, the characteristic "Indicator value"is introduced to the table "Indicators". This characteristic takes into account the rate of the above indicator influence on succeeding. The sum of all the weights of the indicators within one target is one. The attribute "Indicator value" is a certain calculated value, the actual achievement of which indicates a complete solution of the personal target.

Fig. 3 shows the Personal Targets guide, which contains an assessment of personal tasks for the month. For the target "To earn the respect of customers" and the results of the assessment for the indicators "Effective problem solving", "Proactivity", "Ability to influence", "Effective decision-making".

Fig. 4 shows the "Improve leadership skills" task and the results of the assessment according to the indicators "Ability to prioritize", "Skill to work in team", "Organizational Awareness".

The history of actual indicator values is stored in the information register (Fig. 5). 


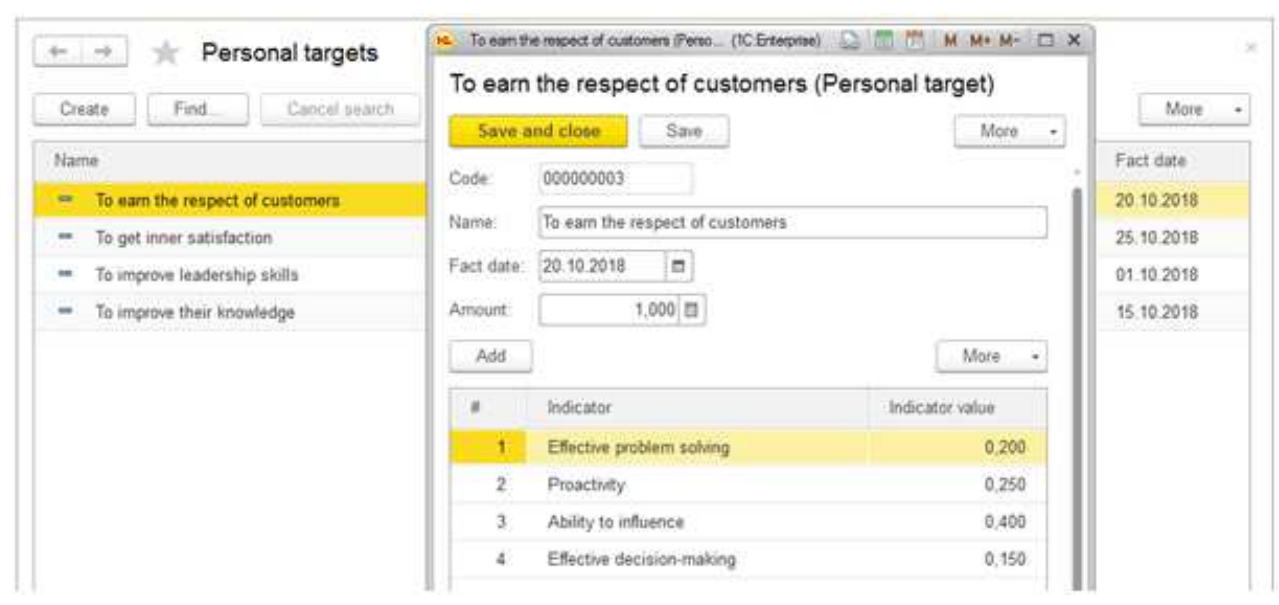

Fig. 3. Personal targets "To earn the respect of customers"

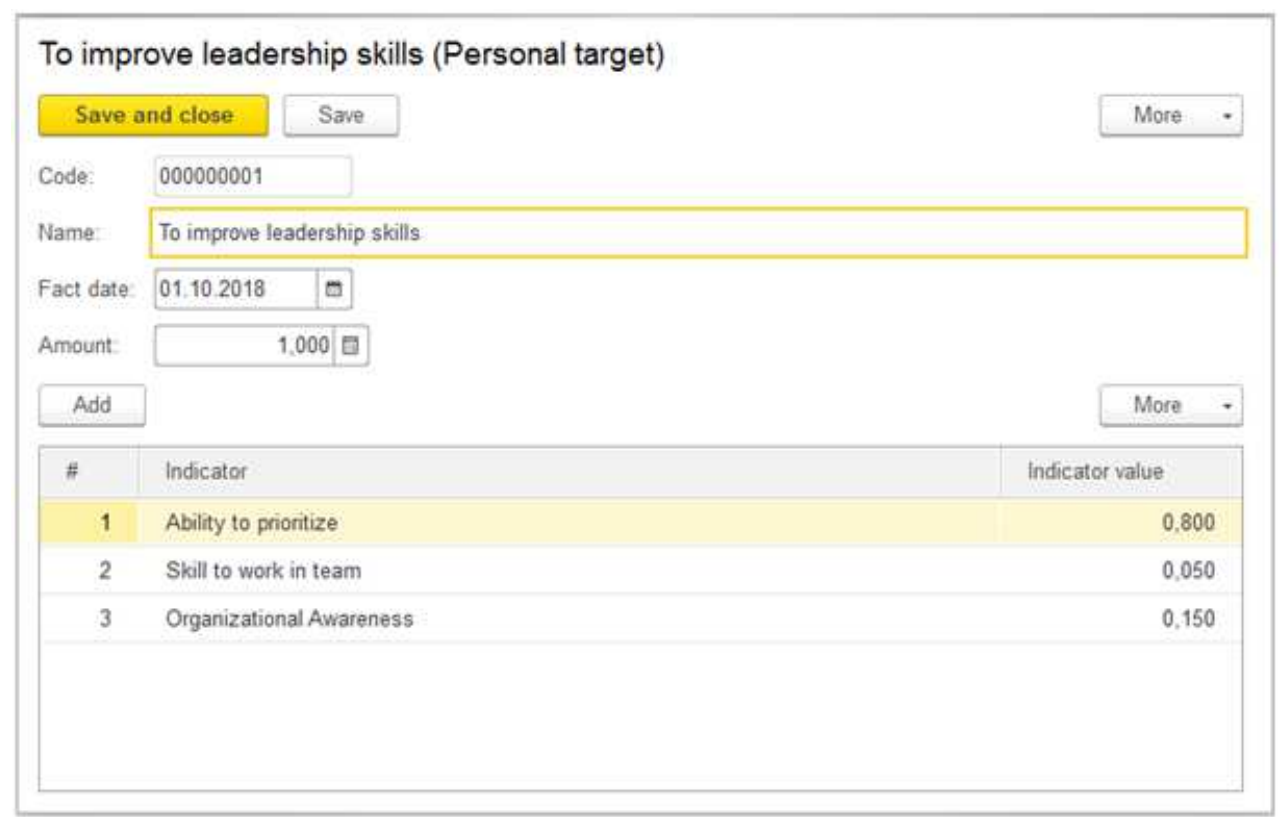

Fig. 4. Personal targets "To improve leadership skills"

The following reports are suggested to be used for getting some analytical information containing resulting aggregated or detailed information, which is formed according to certain standards.

1. Report "BSC-monitoring in terms of key performance indicators" is a monthly general report where all indicators are presented in the personal targets (Fig. 6).

2. "BSC-monitoring in terms of personal targets" report is a monthly general report where all the indicators are presented in terms of performance indicators of each employee as well as indicator value and color indicator of attainment. The color indicator is green when the planned value has been attained, it is yellow when the value has not changed, it is red when the indicator value has gone down (Fig. 7).

3. In the report "The effectiveness of measure influence on the indicator improvement", the list of the above measures is presented. For each measure, we present the following: 


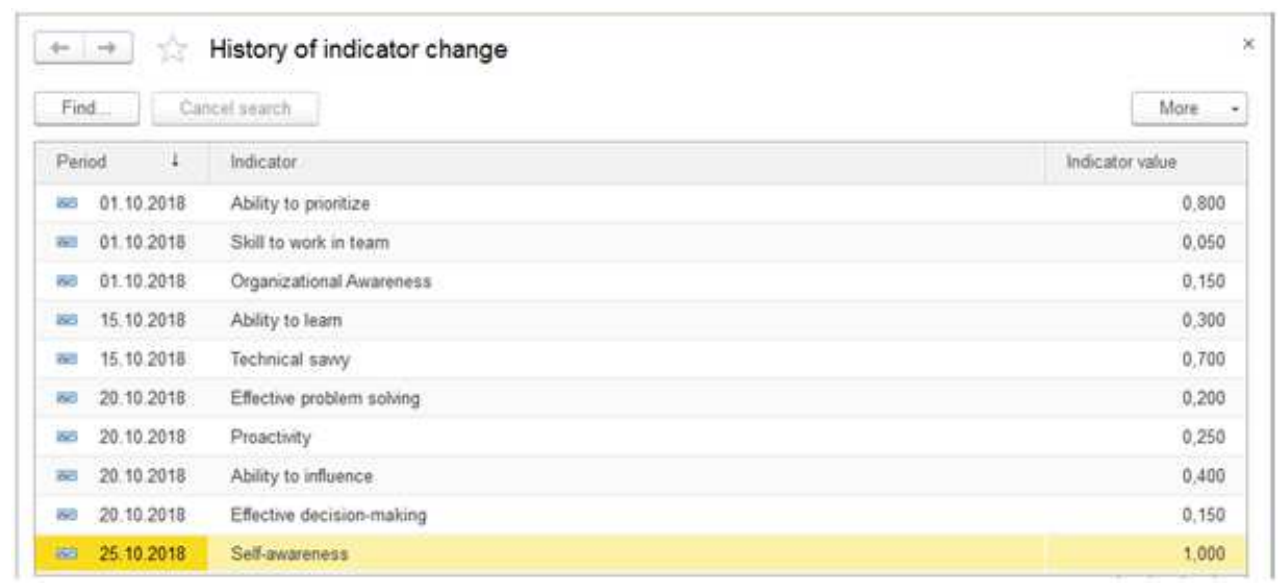

Fig. 5. Register structure "History of indicator changes"

\begin{tabular}{|l|l|l|}
\hline \multicolumn{1}{|c|}{ BSC-monitoring in terms of key performance indicators } \\
\hline Run report \\
\hline Name \\
\hline Indicators. Indicator. Name
\end{tabular}

Fig. 6. Report BSC-monitoring in terms of key performance indicators

date of commencement and expiry date, cost and rate of influence on certain indicators. The list of measures can be reviewed over any period.

\section{Conclusion}

We have used "1C: Enterprise Platform 8.3" (Accounting system of enterprise) to implement the analysis information system for the personal balanced scorecard. The above module can be introduced in "1C: ERP" (Enterprise Recourse Planning). Such expansion of ERP-system capabilities will allow objectively evaluate the competencies and efficiency of each employee within the framework of the Industry 4.0.

The system can be completed with some modules which will analyze indicators which characterize customer relations, interior business-processes, staff situation and development of the enterprise interior infrastructure. 


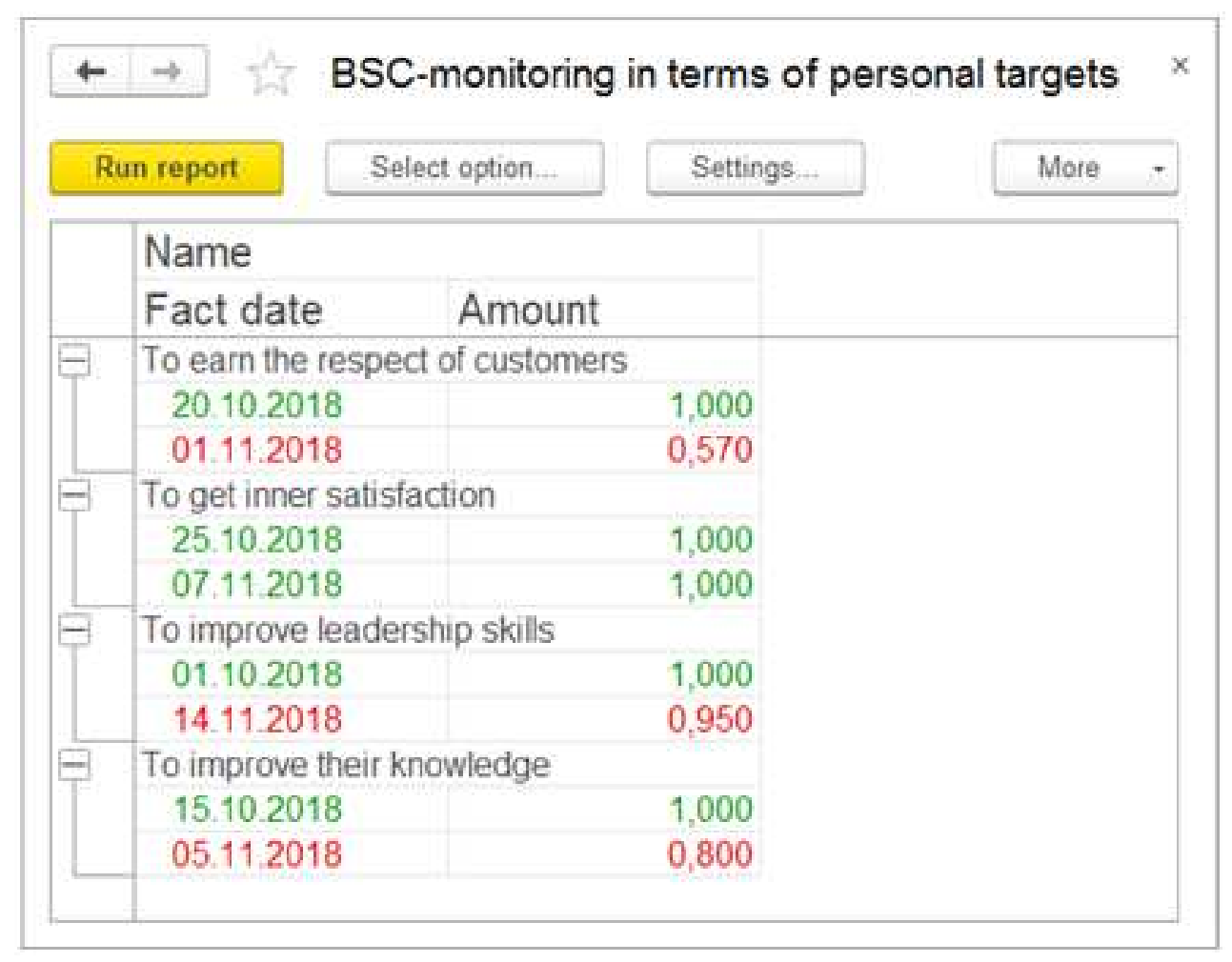

Fig. 7. Report BSC-monitoring in terms of personal targets

Taking into account that today a lot of Russian enterprises use this software, further work in this direction seems to be perspective.

\section{References}

1. Kandalintsev V. G. Innovation Business: Use of Balanced Scorecard. Moscow, Delo ANH Publ., 2010. (in Russian)

2. Kandalintsev V. G. Balanced Management of Enterprise. Moscow, Knorus Publ., 2006. (in Russian)

3. Romanenko O. A. Strategy of External Growth of the Company: Methodical Approaches to Introduction of the Balanced System of Indicators. Economics and Enterprise, 2014, no. 11-3 (52), pp. 772-776. (in Russian)

4. Niven P. R. Balanced Scorecard Step-by-Step: Maximizing Performance and Maintaining Results. Hoboken, 2006.

5. Kaplan R. S., Norton D. P. The Balanced Scorecard: Translating Strategy into Action. Moscow, Olimp-Biznes Publ., 2006. (in Russian)

6. Kaplan R. S., Anderson S. R. Time-Driven Activity-Based Costing: a Simpler and More Powerful Path to Higher Profits. Boston, Harvard Business School Publishing Corporation, 2007. 
7. Logvinova T. V. [Transformation of Functions of Finance Strategic Management]. Financial Management, 2007, no. 1. pp. 20-24. (in Russian)

8. Rampersad H. K., El-Homsi A. TPS-Lean Six Sigma: Linking Human Capital to Lean Six Sigma: A New Blueprint for Creating High Performance Companies. Information Age Publishing, 2007.

9. Rukhlyada N. O. The Use of a Balanced Scorecard for the Effective Development of the Company in the Concept of Strategic Management Accounting. Theoretical and Applied Aspects of Modern Science, 2015, pp. 137-142.

10. Ryazantseva N. A. Ryazantsev D. N. [1C: Enterprise 8.0. Management of Manufacturing Enterprise]. St. Petersburg, BHV-Petersburg, 2006. (in Russian)

11. Khorvart P. Balanced Scorecard as a Business Management Tool. Theoretical and Practical Aspects of Management, 2000, no. 4, pp. 13-22.

Galina A. Pollack, PhD (Techn), Department of Information Technology in Economics, South Ural State University (Chelyabinsk, Russian Federation), pollakga@susu.ru.

Olga V. Ufimtseva, Senior teacher of Department of Information Technology in Economics, South Ural State University (Chelyabinsk, Russian Federation), ufimtcevaov@susu.ru.

Received March 23, 2020.

\title{
АНАЛИЗ КОМПЕТЕНЦИЙ СОТРУДНИКОВ ПРЕДПРИЯТИЯ В ИНДУСТРИИ 4.0
}

\author{
Г. А. Поллак, О. В. Уфимиева
}

Развитие предприятий в рамках Индустрии 4.0 требует от каждого сотрудника профессионального и личного развития. Одной из самых известных концепций управления предприятия, является универсальная система показателей (TPS). Эта система объединяет концепции сбалансированной системы показателей организации (OBSC) и индивидуальной сбалансированной системы показателей (PBSC). Идеи, заложенные в концепциях OBSC и PBSC, объединены общими показателями, которые связаны с результатами развития и обучения каждого сотрудника.

На Российских предприятиях многие ERP-системы разработаны на платформе 1C: Предприятие. В статье предлагается модуль, расширяющий возможности ERPсистемы, который позволяет создать обратную связь между OBSC и PBSC.

Ключевые слова: стратегическое управление; стратегчческие чели; индивидуальнал сбалансированная система показателей (РВSC); ключевые показатели производительности (KPI); программное обеспечение "1C: Предприятие". 


\section{Литература}

1. Кандалинцев, В. Г. Инновационный бизнес. Применение сбалансированной системы показателей / В. Г. Кандалинцев. - М.: Дело АНХ, 2010.

2. Кандалинцев, В. Г. Сбалансированное управление предприятием / В. Г. Кандалинцев. - М.: КНОРУС, 2006.

3. Романенко, О. А. Стратегия внешнего роста компании: методические подходы к внедрению сбалансированной системы показателей / О. А. Романенко // Экономика и предпринимательство. - 2014. - № 11-3 (52). - С. 772-776.

4. Niven, P. R. Balanced Scorecard Step-by-Step: Maximizing Performance and Maintaining Results / P. R. Niven. - Hoboken, 2006.

5. Каплан, Р. С. Сбалансированная система показателей. От стратегии к действию / Р. С. Каплан, Д. П. Нортон. - М: Олимп-Бизнес, 2006.

6. Kaplan, P. S. Time-Driven Activity-Based Costing: a Simpler and More Powerful Path to Higher Profits / P. S. Kaplan, S. R. Anderson. - Boston: Harvard Business School Publishing Corporation, 2007.

7. Логвинова, Т. В. Трансформация функций финансово-стратегического управления / Т. В. Логвинова // Финансовый менеджмент. - 2007. - № 1. - С. 20-24.

8. Рамперсад, X. TPS-Lean Six Sigma. Новый подход к созданию высокоэффективной компании / Х. Рамперсад, А. Эль-Хомси. - М.: РИА Стандарты и качество, 2009.

9. Rukhlyada, N. O. The Use of a Balanced Scorecard for the Effective Development of the Company in the Concept of Strategic Management Accounting N. O. Rukhlyada // Theoretical and Applied Aspects of Modern Science. - 2015. P. $137-142$.

10. Рязанцева, Н. А. 1С: Предприятие 8.0. Управление производственным предприятием / Н. А. Рязанцева, Д. Н. Рязанцев. - С. Петербург: БХВ-Петербург, 2006.

11. Khorvart, P. Balanced Scorecard as a Business Management Tool / P. Khorvart // Theoretical and Practical Aspects of Management. - 2000. - № 4. - P. 13-22.

Поллак Галина Андреевна, кандидат технических наук, дочент кафедрь информачионных технологий в экономике, Южно-Уральский государственный университет (г. Челябинск, Российская Федераиия), pollakga@susu.ru.

Уфимиева Ольга Викторовна, старший преподаватель кафедры информачионных технологий в экономике, Южно-Уральский государственный университет (2. Челябинск, Российская Федерация), иfimtcevaоv@susu.ru.

Поступила в редакиию 23 марта 2020 г. 